\title{
What does legal ethics teaching gain, if anything, from including a clinical component?
}

\author{
Anna Cody ${ }^{1}$ \\ University of New South Wales, Australia
}

acody@unsw.edu.au

In some law schools legal ethics have been taught very conservatively, focussed on the law of lawyering with a heavy emphasis on 'professional rules' and how to ensure solicitors and barristers behave within the professional rules ${ }^{2}$ Others however have proposed different models for thinking about lawyering, lawyers' ethical duties and the role of lawyers within the legal system. In this article, legal ethics, ethical decision making and values are explored. I ask what value can be gained by including a clinical component within a standard legal ethics course even when it is a short exposure experience. I explore the range of meanings ascribed to ethics and professional responsibility, and the connection between personal and professional identities. Finally using three vital elements within the definition of an

\footnotetext{
${ }^{1}$ Anna Cody is an Associate Professor of Law at University of New South Wales and Director of Kingsford Legal Centre, Australia. I would like to acknowledge the insights and assistance from Professor Judith Welch Wegner, Professor Alex Steel, Meena Sripathy and the two blind peer reviewers in writing this article.

${ }^{2}$ Australia now has Model rules of legal practice which are being used throughout each State and Territory.
} 
ethical legal professional, I evaluate whether the clinical component contributes to teaching students about how to be an ethical legal professional. I draw from the Best Practices of Australian clinical legal education ${ }^{3}$ to assist with this process, and discuss some additional learnings which students gain from seeing legal practice modelled for them in a community legal centre, located within a university faculty of law. Some of the challenges of developing an effective clinical component are explored such as the importance of training volunteer lawyer supervisors and how to assess the learning by students. The ways of sharing the individual learning across the student cohort is also a further challenge.

\section{DEFINING LEGAL PROFESSIONALISM}

In England ${ }^{4}$, as well as in Australia, there is frequently a lack of clearly defined goals about the teaching of ethics, nor are there clearly defined values to teach. This is in part due to the fact that the "written ethics are found in what are essentially disciplinary, as opposed to aspirational, codes." ${ }^{5}$ Ethics teaching frequently focuses

\footnotetext{
${ }^{3}$ Best Practices in Australian Clinical legal education, , http://www.olt.gov.au/project-strengthening-australianlegal-ed-clinical-experiences-monash-2010, Adrian Evans, Anna Cody, Anna Copeland, Jeff Giddings, Mary Anne Noone, Simon Rice. Office for Learning and Teaching, 2013.

${ }^{4}$ Kevin Kerrigan, 'How do you feel about this client?"- A commentary on the clinical model as a vehicle for teaching ethics to law students. 2007 Int'l I Clinical Legal Educ 72007.

${ }^{5}$ Julian Webb, 'Conduct, Ethics and Experience in Vocational Legal Education" in Ethical Challenges to Legal Education and Conduct, Hart publishing, Oxford 1998 quoted in Kerrigan 'How do you feel about this client?"-A commentary on the clinical model as a vehicle for teaching ethics to law students. 2007 Int'I J. Clinical Legal Educ 72007.
} 
on professional responsibility rules $^{6}$ or law rather than a discussion of the sort of lawyers we want to produce in our law schools, and the ethical frameworks to use when making decisions.

Frequently students say that they want to be 'professional' and yet when probed, can't really describe what this means. They will often respond using words such as 'objective', 'skilled', 'experienced'. Sometimes they will recognise that a professional has a responsibility not just to themselves but to the community also. They frequently refer to the importance of professional work and the relatively high status attached to it. It is a challenge for students to be specific in their definitions.

There is an interesting tension between what it means to be 'professional' and at the same time, being yourself within your work. Many have explored the tension between being a lawyer, a mouthpiece or advocate for someone else, arguing the law on behalf of someone and this being professional. But this can create tensions for those whose personal values may clash with the position they are arguing? Webb ${ }^{8}$ has explored in depth the concept of 'ethics' and 'being' and the importance of measuring who you are as a lawyer, as well as what you do. As discussed below, in order to ensure a happy, well functioning legal professional, the person you are as a lawyer is also important, in line with what you do.

\footnotetext{
${ }^{6}$ In England ethics are frequently taught through rules and in Australian and the USA this is similarly the case. Nigel Duncan and Susan L. Kay, 'Addressing Lawyer Competence, Ethics and Professionalism', in Frank Bloch ed, The Global Clinical Movement, 2011 London OUP.

${ }^{7}$ Christine Parker and Adrian Evans, Inside Lawyers Ethics, $2^{\text {nd }}$ Ed. Melbourne, Cambridge University Press 2014.

${ }^{8}$ Julian Webb, Being a Lawyer/Being a Human Being, 5 Legal Ethics 1302002
} 
Professional identity highlights social responsibility or ethics but also includes creating competent ${ }^{9}$ legal professionals who are responsible to the individual client as well as the community. ${ }^{10}$ Each of the professions recognises that in addition to the individual relationship with a client or a patient, a professional also has a responsibility to the community to contribute to it in some form, to provide a service. The Carnegie Foundation for the Advancement of Teaching has reviewed the education of various groups of professionals and discusses "professional formation toward a moral core of service to and responsibility for others"11.

A number of attempts have been made to try to define professionalism in light of these tensions. The MacCrate Report identified key values which are essential to lawyers. These include :
a) Provision of competent representation;
b) Striving to promote justice, fairness and morality;
c) Striving to improve the profession;
d) Professional self development. ${ }^{12}$

\footnotetext{
${ }^{9}$ In the workshop given on the theme of clinical components within ethics subjects at the 2014 ICJLE conference, participants included 'competence' as one of the key ethical teachings which should be included within even a short clinical component.

${ }^{10}$ William M Sullivan et Al, Educating Lawyers: Preparation for the Profession of Law (2007) (hereinafter the Carnegie report), as quoted in Tony Foley, Margie Rowe, Vivien Holmes and Stephen Tang, "Teaching professionalism in legal clinic- what new practitioners say is important" International Journal of Clinical Legal Education, Vol. 17, 2012.

${ }^{11}$ Neil Hamilton and Verna Monson, 'Legal Education's Ethical challenge: Empirical research on how most effectively to foster each student's professional formation (professionalism)' University of St Thomas Law Journal, Vol9:2 2012 p 332

${ }^{12}$ Report of the Task Force on law Schools and the Profession, Narrowing the Gap: Legal Education and Professional Development-An Educational Continuum (American Bar Association July 1992), (the MacCrate Report")
} 
Noone and Dickson have defined their requirements for a professionally responsible lawyer as someone who:

1.) fulfils the duties attached to a fiduciary relationship;

2.) is competent in the work they perform;

3.) communicates often, openly and clearly with their client;

4.) does not encourage the use of law to bring about injustice, oppression or discrimination;

5.) identifies, raises and discusses ethical issues with current/potential clients;

6.) seeks to enhance the administration of justice and actively engages in serving the community ${ }^{13}$.

Hyams builds on the Noone and Dickson definition, specifically adding to their six points, with three additional points of his own. These are:

1.) the lawyer should be able to work in an autonomous way-in an independent, self-sufficient and self-directed fashion;

2.) the lawyer should be able to exercise judgment-not only relating to how to resolve a client's problems, but reflective judgement of their own behaviours and actions;

3.) s/he should have an ongoing commitment to lifelong education-over and above that which is required by continuing professional development points.

Hyams describes this last point as requiring two things--first, an understanding that good lawyering and professionalism require an ongoing process of understanding personal limitations and a commitment to remain fresh, innovative and knowledgeable in professional work. Second, it requires the tools to put this

\footnotetext{
${ }^{13}$ Mary Anne Noone and Judith Dickson, 'Teaching Towards a New Professionalism: Challenging Law Students to Become Ethical Lawyers' 4 Legal Ethics 127 2001, 144
} 
understanding and commitment into action ${ }^{14}$. Hyams refers to the understanding that all professionals have an obligation to contribute to the community in some form ${ }^{15}$.

Each of these definitions includes the key aspect:

- working towards or contributing to justice, fairness and the improvement of the legal system and serving the community, as part of the role of a lawyer.

The other two aspects which are used in this article as a framework of analysis are:

- gaining a sense of autonomy and self direction; and

- ongoing reflection and continual improvement.

The last two points are key aspects of an ethically responsible lawyer as the ability to reflect on oneself, how you are and what you do as a lawyer, is vital to being able to improve and be a competent lawyer. Ongoing reflection on how a lawyer contributes to the legal system and its ability to deliver justice is also necessary for any lawyer to be able to contribute to the justice system and serve the community. Autonomy and self direction is only an element in the Hyams definition and yet if autonomy is understood as being connected to motivation theory and an expression of self (discussed below), then it unites individual values with professional work and is thus a vital element of a responsible lawyer. These 3 points that I have identified

\footnotetext{
${ }^{14}$ Ross Hyams, 'On teaching students to 'act like a lawyer': What sort of lawyer?'. 13 Int'l J. Clinical Legal Educ. 21 2008, 44.

${ }^{15}$ Ross Hyams, “On teaching students to 'act like a lawyer': What sort of lawyer?”. 13 Int'l J. Clinical Legal Educ. $212008,21$.
} 
also fit within a community legal centre practice. They will be used to evaluate whether or not a clinical component, based in a community legal centre ${ }^{16}$, where students interview disadvantaged clients, can impact on and develop these 3 key aspects of professional identity, even where it is a brief exposure experience. The 3 elements are interconnected and contribute to each other.

The choice of any 3 elements is therefore always going to be arguable. I choose these 3 elements because they are vital to a lawyer being an ethical legal practitioner and because a clinical component within a community legal centre has the potential to teach these 3 key elements.

\section{INDIVIDUAL VALUES AND PROFESSIONALISM; ETHICAL DECISION-}

\section{MAKING}

In addition to the difficulties in defining what professionalism means in a legal context, a further significant issue exists in negotiating the connection between individual values and professionalism. There are deep concerns about the ways in which legal education, and legal practice can be alienating for law students ${ }^{17}$ and

\footnotetext{
${ }^{16}$ There are over 200 community legal centres in Australia which provide free legal help (advice, casework, community education and law reform services) to disadvantaged members of the community. www.naclc.org.au

${ }^{17}$ Larry Krieger 'The Inseparability of Professionalism and Personal Satisfaction: perspectives on Values, Integrity and Happiness, 11 Clinical L.Rev. 4125 (2005), and Tony Foley, Margie Rowe, Vivien Holmes and Stephen Tang, "Teaching professionalism in legal clinic- what new practitioners say is important" International Journal of Clinical Legal Education, Vol. 17, 2012
} 
lawyers. Students in the common law jurisdictions, learn law largely through the Socratic method. This involves using cases to demonstrate the development of law and legal principle. The rich complexity of facts and people's lives are largely extracted out of the Socratic method ${ }^{18}$ and thus in large part, the human depth is also removed. Students are taught to argue a legal principle and doctrine, through case and statute law, and while their views of the particular legal doctrine may be sought at some point, they are secondary to being able to argue the development of the law. This way of constructing argument can be alienating to students. Some have argued that, "legal education and early lawyering experiences can tend to erode integrity by separating people from their personal values and beliefs, conscience, truthfulness, and intrinsic needs for caring and co- operation" ${ }^{19}$.

Others frame this a little more mildly, as the importance of a 'value-match' between a lawyer's own values and the values of their firm. ${ }^{20}$ Or that even earlier, it is important to find a value match within the law school experience before entering practice $^{21}$.

\footnotetext{
${ }^{18}$ UNSW doesn't teach in a pure Socratic method and there is a range of practices that are more contextualised - such as structured class participation. See Alex Steel, Julian Laurens and Anna Huggins, Class Participation as a Learning and Assessment Strategy in Law: Facilitating Students' Engagement, Skills Development and Deep Learning (2012) 36(1) UNSW Law Journal 30

${ }^{19}$ Larry Krieger, 'The Inseparability of Professionalism and Personal Satisfaction: perspectives on Values, Integrity and Happiness, 11 Clinical L.Rev. 4125 (2005)

${ }^{20}$ Tony Foley, Margie Rowe, Vivien Holmes and Stephen Tang "Teaching professionalism in legal clinic- what new practitioners say is important" International Journal of Clinical Legal Education, Vol. 17, 2012

${ }^{21}$ Paula Lundstad, Walk the Talk: Creating Learning Communities to Promote a Pedagogy of Justice, 4 Seattle J. Soc. Just. 613 2005-2006;
} 
The notion of 'values' has an obviously wide meaning. Some refer to it meaning a person's individual, personal and professional values, others refer to it as purely professional values ${ }^{22}$. This debate connects to the debate around professionalism. If one considers professionalism to be 'objective', without judgement, then personal values should not come into professionalism. However in this article, professionalism is defined to include recognising a responsibility to the community in the practice of law. This inevitably means more than just professional values and includes a person's sense of who they are, and what it means to them personally to be a lawyer. This is a view expounded by law and ethics teachers who connect the two $^{23}$. Many argue that the 2 cannot be separated as a lawyer is more than what they do but also who they are ${ }^{24}$.

The connection between self and professionalism is something which theorists Christine Parker and Adrian Evans ${ }^{25}$ have explored. They posit a theory of ethical frameworks with 4 key frameworks within which lawyers make ethical decisions. A lawyer may choose to use different frameworks at different times, or regularly feel more comfortable in one framework than another. Rarely does a lawyer always

\footnotetext{
${ }^{22}$ Larry Krieger'The Inseparability of Professionalism and Personal Satisfaction: perspectives on Values, Integrity and Happiness, 11 Clinical L.Rev. 4125 (2005), and Tony Foley, Margie Rowe, Vivien Holmes and Stephen Tang 'Teaching professionalism in legal clinic- what new practitioners say is important'. IJCLE, Vol 17 2012.

${ }^{23}$ Julian Webb, Being a Lawyer/Being a Human Being, 5 Legal Ethics 130 2002, Catherine Klein, Leah Wortham and Beryl Blaustone, Autonomy-Mastery-Purpose: Structuring Clinical Courses To Enhance These Critical Educational Goals, 17-18 Int'l J. Clinical Legal Educ. 1052012 , Paula Lundstad, Walk the Talk: Creating Learning Communities to Promote a Pedagogy of Justice, 4 Seattle J. Soc. Just. 613 2005-2006; Neil Hamilton and Verna Monson, 'Legal Education's Ethical challenge: Empirical research on how most effectively to foster each student's professional formation (professionalism)' University of St Thomas Law Journal, Vol9:2 2012. ${ }^{24}$ Julian Webb, Being a Lawyer/Being a Human Being, 5 Legal Ethics 130 2002, Adrian Evans and Christine Parker, 'Inside Lawyers' Ethics', 2013, Cambridge University Press, Ch 2.

${ }^{25}$ Christine Parker and Adrian Evans, 'Inside Lawyers' Ethics', $2^{\text {nd }}$ ed. 2014, Cambridge University Press, p32.
} 
operate out of one framework. The 4 frameworks are: adversarial advocate in which a lawyer's role is to advocate zealously for the client's interests within the bounds of the law. Another is that of responsible lawyer who is seen predominantly as an officer of the court and the lawyer is responsible for making the law and the legal system work as fairly as possible. A moral activist model of ethics emphasises the importance of lawyers' position within society and their role in engaging in law reform activity to make law fairer and also to advise clients about a moral course of action. The fourth model is the ethics of care lawyering. In this the lawyer's responsibility to other people and to maintain relationships, and to avoid harm is the key consideration ${ }^{26}$.

Students have the opportunity to explore ethical frameworks through the clinical component of their legal ethics course.

\section{HOW THE CLINICAL COMPONENT WORKS}

The clinical component functions as a part of the normal operations of a functioning community legal centre. This Centre, Kingsford Legal Centre ${ }^{27}$, sees over 1800 clients each year providing free legal advice to them, as well as undertaking casework for over 300 clients each year and engaging in community education and law reform and policy work. The Centre runs 3 evening advice clinics each week

\footnotetext{
${ }^{26}$ ibid 7.

${ }^{27}$ www.kingsfordlegalcentre.org.au
} 
with 10-12 clients given advice at each advice clinic. Each evening advice clinic is supervised by a staff clinical supervisor/solicitor with up to 6 volunteer solicitors and barristers who give their time voluntarily (pro bono).

All the students who participate in the clinical component are studying the course Lawyers, Ethics and Justice. Some are undergraduate ${ }^{28}$ students completing a combined degree and so are mostly in their $3^{\text {rd }}$ year of a 5 year program. Other students are Juris doctor ${ }^{29}$ students who are studying law as a graduate degree and these students are generally in their first or second semester of a 3 year degree program. Students, before coming to the Centre are given a 2 hour class on the functioning of the Centre and an introduction to interviewing skills in their regular class time of Lawyers, Ethics and Justice. On arrival at the Centre before their assigned evening advice clinic a clinical elective student (who is studying an elective clinical course over the whole semester at the Centre) and a clinical supervisor teach them about the internal processes of the Centre, how to check for conflict of interest, give them a further explanation of the duty of confidentiality and teach them key points about working with interpreters. They also explain the support mechanisms available to students and give them a basic safety training.

After this 2 hour induction, students begin to take instructions from clients. After they have taken initial instructions from their first client, they leave the client waiting, go and discuss the case with a volunteer lawyer/supervisor and the

\footnotetext{
${ }^{28}$ http://www.handbook.unsw.edu.au/undergraduate/courses/2015/LAWS1230.html

${ }^{29}$ http://www.handbook.unsw.edu.au/undergraduate/courses/2015/LAWS1230.html
} 
supervising solicitor/clinical supervisor, devise the legal advice in collaboration with the volunteer lawyer/supervisor, then return with the volunteer lawyer/supervisor. The volunteer lawyer gives advice while the student makes notes of the interview, and records the advice given. The student and volunteer solicitor have a short debrief after the interview, before the student sees another client to take instructions.

This article examines whether a brief, intense clinical component of a substantive ethics course can teach key aspects of ethics. As mentioned above, these are:

- working towards or contributing to justice, fairness and the improvement of the legal system and serving the community, as part of the role of a lawyer;

- the students/lawyers development of autonomy and self direction; and

- the need for ongoing reflection on their role, and continual improvement.

Such a component, even if only short, can give students a sense of how law can impact on disadvantaged people. It contributes to students' understanding of HOW they can use their law degrees to improve justice and the legal system as well as giving them a sense of autonomy. By providing a clinical component with real clients early in a law degree, students are exposed to a particular area of legal practice with which they must align their own values. Each decision on a case, will affect the life of the client as legal issues have a deep impact on the lives of 
disadvantaged clients ${ }^{30}$. Working with disadvantaged clients, students see the ways in which law can impact harshly in people's lives and thus their questioning of 'justice' and the 'law' is enlivened. The framework for thinking about ethical decision making and their role as future lawyer, is therefore particularly relevant.

Additional learnings gained by students will be explored. In additional, attention will be given to whether the clinical component meets the Best Practices in Australian Clinical Legal Education. ${ }^{31}$ This report was the first of its kind in Australia, documenting each of the clinical programs in place over the period 2009 to 2011 ${ }^{32}$. It was guided by an international reference group of clinical legal education experts, and an Australian advisory council. It documented existing practice across all clinical programs through a survey and interviews with every program. From this empirical research, the research group developed the Best Practices in Australian Clinical Legal Education as a guide for those reviewing clinical programs and creating new ones, in order to develop high quality, rigorous clinical programs.

\footnotetext{
${ }^{30}$ NSW Law and Justice Foundation research on the impact of legal problems on disadvantaged clients. Coumarelos, C, Macourt, D, People, J, MacDonald, HM, Wei, Z, Iriana, R \& Ramsey, S 2012, Legal AustraliaWide Survey: legal need in Australia, Law and Justice Foundation of NSW, Sydney.

${ }^{31}$ Best Practices in Australian Clinical legal education, , http://www.olt.gov.au/project-strengtheningaustralian-legal-ed-clinical-experiences-monash-2010, Adrian Evans, Anna Cody, Anna Copeland, Jeff Giddings, Mary Anne Noone, Simon Rice. Office for Learning and Teaching. 2013.

${ }^{32}$ Regional reports and final report Best Practices in Australian Clinical legal education, http://www.olt.gov.au/project-strengthening-australian-legal-ed-clinical-experiences-monash-2010, Adrian Evans, Anna Cody, Anna Copeland, Jeff Giddings, Mary Anne Noone, Simon Rice. Office for Learning and Teaching. 2013.
} 
TEACHING ETHICS THROUGH A CLINICAL COURSE: WHY THIS IS A

\section{VALUABLE WAY TO TEACH ETHICS}

Ethics have mostly been formally taught in the classroom. However whenever law ${ }^{33}$ is taught through clinical subjects, it is unavoidable that ethics issues and therefore ethics teaching ${ }^{34}$ occurs. Additionally there are some law schools which have chosen to teach ethics either wholly through a clinic, or incorporating clinical components. For example, at the Catholic University ${ }^{35}$ in Washington DC elements of clinical teaching are incorporated into their Professional Responsibility course. In many clinical courses, learning about ethical responsibilities is one of the learning objectives of the course. ${ }^{36}$ There are also clinical courses whose specific aim is to teach legal ethics and professional responsibility ${ }^{37}$. An alternative is to include a clinical component in an ethics course and this approach may be equally effective.

\footnotetext{
${ }^{33}$ Historically, law teaching has passed through many permutations. After the division between the academe and professional practice, Jerome Frank proposed in the early $20^{\text {th }}$ century that law could be taught through a clinical law school. Some law schools have modelled themselves on being 'clinical law school' (Newcastle University NSW and Northumbria University) but this is not the norm.

${ }^{34}$ See the entry for Latrobe University at p 15 and the entry for University of New South Wales at page 36. Clinical Legal Education Guide, Your guide to courses offered by Australian Universities in 2014, Kingsford Legal Centre. 2014.

http://www.klc.unsw.edu.au/sites/klc.unsw.edu.au/files/55386_clinical_legal_education_guide_web.pdf ${ }^{35}$ Leah Wortham, interview with the author, December 2014 and Leah Wortham, Thanks for the Book and the Movie, 10 Clin. L. Rev. 399 (2003) (invited submission to symposium honoring the $25^{\text {th }}$ anniversary of publication of Gary Bellow \& Bea Moulton, The Lawyering Process (1978)).

${ }^{36}$ Clinical Legal Education Guide, Your guide to courses offered by Australian Universities in 2014, Kingsford Legal Centre. 2014.

http://www.klc.unsw.edu.au/sites/klc.unsw.edu.au/files/55386_clinical_legal_education_guide_web.pdf ${ }^{37}$ The course run by Latrobe University focuses on professional responsibility and has been run at a range of legal services including West Heidelberg Community Legal service, Preston Legal Aid among others. Best Practices Australian clinical legal education, Regional report Victoria and Tasmania 2011 page 5. http://law.monash.edu.au/about-us/legal/olt-project/regional-reports/index.html Clinical Legal Education Guide, Your guide to courses offered by Australian Universities in 2014, Kingsford Legal Centre. 2014.page 16. http://www.klc.unsw.edu.au/sites/klc.unsw.edu.au/files/55386_clinical_legal_education_guide_web.pdf
} 
"Once they encounter a client, the blind faith that there is a 'truth' or a 'law' that can be applied must give way to a more sophisticated understanding. Clients' cases rarely present simple facts that lend themselves to right and wrong answers. It is the complexity and unpredictability of working with real people that makes clinical legal education so rich." 38 This complexity of clients' cases is rich ground for learning about ethical decision- making and the widespread occurrence of ethical issues.

However it cannot be assumed that simply by placing students in a clinic, they will learn 'ethics' and ethical decision- making. This does not occur via a process of osmosis. It has to be consciously planned and incorporated ${ }^{39}$. The literature on such clinical approaches highlights a number of important pedagogical matters that are necessary to achieve fuller learning outcomes. Rather than assume that experience itself will teach students, the importance of de-brief and reflection is essential. Students need the opportunity to talk with each other about what they are learning and reflection is a key part of the learning process ${ }^{40}$. The groundedness of teaching professional responsibility or ethics through a clinic, allows discussions such as the importance of cultural competence ${ }^{41}$. The diversity of clients, client

\footnotetext{
38 Jane Aitken, 'Provocateurs for Justice', 7 Clin.L.Rev. 287 at page 292.

${ }^{39}$ Some have argued that a clinic is not the best place to teach ethics because the ways in which ethical issues arise are unpredictable which means that students will have varying experiences of ethical issues and range of different issues. Despite this, ethical issues can be shared and the learning spread amongst a group of students through class discussions, class presentations, group debriefs. Margaret Martin Barry and Peter A. Joy, 'Clinical Education for This Millenium: The Third Wave', 7 Clinical L. Rev. 1 2000-2001

${ }^{40}$ Margaret Martin Barry and Peter A. Joy, 'Clinical Education for This Millenium: The Third Wave', 7 Clinical L. Rev. 1 2000-2001

${ }^{41}$ Antoinette Sedillo Lopez, Teaching a Professional Responsibility Course: Lessons Learned From the Clinic, 26 J. Legal Prof. 1492002.
} 
experience and the legal issues clients face, provide rich learning for students around cross cultural communication and the importance of working effectively with a broad range of culturally diverse clients. Class-room components of clinical subjects should therefore also include training on cultural competence.

Conceptualising the role of a clinical office as a role model in legal practice about how a legal practitioner should behave and what ethical decision-making means, is also highly significant. There are legitimately a range of views about what is ethical legal practice and appropriate lawyering styles and approaches. The individual behaviour of the clinic lawyers which students observe, give students rich material to critique, analyse and reflect on how to be a lawyer. As Noone et al note, 'Through working with solicitors and being able to observe first hand different lawyering styles, students will begin to develop a deep understanding of ethical practice' ${ }^{\prime 2}$.

Clinics can also highlight the public nature of the work of lawyers and therefore, the public responsibility that lawyers also hold ${ }^{43}$. When the Latrobe University ethics course was offered through West Heidelberg Community legal service it included a component which encouraged clinical students to recognise the limitations of the law and develop law reform solutions to problems which they identified through their work on client cases ${ }^{44}$. Students, by identifying problems with the law and

\footnotetext{
42 Mary Anne Noone, Judith Dickson and Liz Curran, 'Pushing the Boundaries or Preserving the Status Quo? Designing Clinical Programs to Teach Law Students a Deep Understanding of Ethical Practice' (2005) 8 International Journal of Clinical Legal Education 104, 111.

${ }^{43}$ Parker, S 2001, 'Why Lawyers Should do Pro Bono work' 19 (1 and 2) Law and Context.

${ }^{44}$ Liz Curran (2004) 'Responsive Law Reform Initiatives by Students on Clinical Placement at La Trobe Law' 7(2)

Flinders Journal of Law Reform 287.
} 
then by taking an active role in coming up with solutions, were already in the role of responsible lawyer or moral activist lawyer, responsible for ensuring that law and the legal system operate as fairly as possible. Thus the model of ethical lawyering which Parker and Evans discuss ${ }^{45}$ was actively structured into the clinical course.

Other clinical courses generally aim to teach ethics as one of their principal learning objectives. This is defined as being about teaching law in context and the role of law in society as well as the role of lawyers in society. ${ }^{46}$ These learnings are possible within a full clinical course spanning over a semester, with students attending between 1 and 2 days a week at their clinical site, whether it be a community legal centre, a law reform agency or legal regulation authority.

\section{EMBEDDING CLINICAL COMPONENTS WITHIN COURSES.}

Having outlined the key issues around professionalism and legal ethics and how clinical courses have the potential to explore these issues, this section discusses the extent to which it is possible to teach the 3 key elements, when a clinical component is embedded within an ethics course ${ }^{47}$, using the example of the clinical component at University of New South Wales, Australia, Kingsford Legal Centre.

\footnotetext{
${ }^{45}$ Parker and Evans identify the model of 'responsible lawyer' who is an officer of the Court and who is concerned to make the legal system function smoothly and fairly. Table 2.2 Chapter 2, Adrian Evans and Christine Parker, Inside Lawyers Ethics, $2^{\text {nd }}$ ed, Melbourne, Cambridge University Press 2013.

${ }^{46}$ Kevin Kerrigan, 'How do you feel about this client?"- A commentary on the clinical model as a vehicle for teaching ethics to law students. 2007 Int'l I Clinical Legal Educ 7 2007, p16.

${ }^{47}$ Other Australian courses which include a clinical component in Australia are the family law and dispute resolution courses developed by Charles Darwin University in the Northern Territory. This clinical component involves students studying in Darwin the theoretical component of Family law or Dispute resolution over a period of 10 weeks, then travelling over $5000 \mathrm{~km}$ south to work for 2 weeks in a community legal centre in
} 


\section{Working towards or contributing to justice, fairness and the improvement}

\section{of the legal system and serving the community, as part of the role of a lawyer;}

In this post client interview debrief, and also in the initial briefing of the volunteer lawyer by the student there are a range of issues which often emerge. These include:

a). a solicitor must act on the instructions of a client and if a client has a disability how do lawyers deal with the client? Does a psychiatric disability impact on how a lawyer thinks about a client's ability to give instructions? What is disability? How are clients impacted within the legal system by having a disability?

b). Who are the legal profession? Who are clients? Does the limited diversity of the legal profession impact on the experience of disadvantaged clients seeking legal help?

c). What are conflicts of interest? How should a legal practice manage conflicts of interest within families?

d). What does acting on instructions mean?

e). What is a lawyer's responsibility when asked for advice about doing something which is illegal?

f). What is the role of a lawyer and the limit on students who cannot give legal advice?

Northern Victoria which specialises in family law. The other course in Australia as discussed in the Best Practice research project is the LaTrobe Judicial mentoring component which is a component of Family, Society and law; and Criminal Procedure and Evidence. www.OLTC Regional reports, Northern Territory, and Victoria and Tasmania. 
g). How much information should lawyers give clients about why they don't have a good case, taking into account issues of client autonomy issues versus complexity/paternalism/disadvantage?

This range of issues is indicative of the type of issues that arise. It is very wide ranging and depending on the clients who seek legal advice, the issues they raise vary. Additionally the discussion which ensues about these issues can vary, depending on the volunteer lawyer/supervisor who is working with the client and student. The strategy the Centre has developed for ensuring that some of these issues are discussed is to encourage volunteer lawyers/supervisors to analyse with the student any issues which arose during the interview process. The staff clinical supervisor/solicitor may also participate in these discussions. The two challenges with this approach are: the variability of the issues which arise, and the ability of volunteer lawyers to identify issues and discuss them appropriately.

CHALLENGES IN STUDENTS THINKING ABOUT THEIR ROLE AND CONTRIBUTING TO THE COMMUNITY

Some of the volunteer lawyer/supervisors come from a legal services/legal aid background and are accustomed to working with disadvantaged clients. These lawyers have, for example, thought through issues of working with clients with disability whose ability to give instructions may be challenged in some way, or issues of working with culturally diverse clients. There are also lawyers from large 
commercial firms and small suburban practices. Each volunteer lawyer/supervisor brings their perspective on the issues named above. Because of this, each student will experience a different debrief also, not only because they see different clients but because each lawyer will approach the client uniquely. Some may be able to see structural injustices more readily, others not. This variability is both a weakness of the clinical component and a strength.

It is a strength because it demonstrates to students that each lawyer has to grapple with issues themselves individually, with support, but that there isn't a 'one right answer' to ethical issues. Each lawyer brings their experience, individual values and perspectives to the discussion. Often the most interesting discussions will be among the group of lawyers and the staff clinical supervisor about how to deal with an issue, and students observe these and can also participate in them. Students may observe disagreement or robust discussion about how to deal with a particular client. This emphasises to students that ethical issues are not clear cut and there are a range of ways of dealing with issues.

Because the issues which arise from each clinical experience vary so substantially between students, it is a challenge to ensure these individual issues can be shared within a larger group. The lessons which are available to be learnt from each of the issues are not made available to all students, rather they are only available to a few students, those present at the evening advice session. This is a weakness of the 
clinical component as the full learning potential of the issues which arise in each evening advice session, is not fully developed across the cohort of students.

Two ways of deepening and sharing the individual learning would be to ask some students to present verbally on their specific experiences during their interview session, to the larger class, and also draw on student's individual experiences when discussing broader ethical issues such as the duty of confidentiality or fiduciary relationships. Students could also gain points in their grades for class participation ${ }^{48}$ for using anonymised examples from the interviewing clinical component. These would be two mechanisms to draw greater learning from the clinical component. The added benefit of these approaches would be that it would also enable peer to peer learning, beginning the process within the formal class setting, of drawing on peers to explore and resolve ethical issues. This would have substantial benefit for the students' later legal practice ${ }^{49}$. Another method for ensuring peer to peer learning would be to require students to comment on 3 other student assignments.

By requiring students to complete a set reflective assignment which asks students to reflect on any ethical issues which arose during their interviewing session, students are all asked to identify specific issues, even though they will have experienced different issues. In this way the experience is assessed equally among the group,

\footnotetext{
${ }^{48}$ At UNSW students are graded for their class participation including preparation for class, ability to identify issues and contribute to discussion among other criteria.

${ }^{49}$ Alex Steel, Julian Laurens and Anna Huggins, 'Class Participation as a Learning and Assessment Strategy in Law: Facilitating Students' Engagement, Skills Development and Deep Learning' (2012) 36(1) UNSW Law Journal 30
} 
although the insights that students gain are not shared with the group, limiting the potential of peer to peer learning.

RESPONSIBILITY TO CONTRIBUTE TO THE LEGAL SYSTEM TO MAKE IT FAIRER

The other implicit message which is given by incorporating a clinical component within a core course on legal ethics, is that universities and law faculties have a responsibility to respond in some way to unmet legal need. Students contribute actively in providing legal services to disadvantaged people. By situating a clinical component within an 'in house' clinic it gives the clear message to students that this is the core work of the law faculty and integrates students into this role. It communicates to those students that they are part of the legal system, participating in it and they are giving help to people who need legal help and who can't afford to pay for it. It then prompts the question, what responsibility does each lawyer have, within the legal system, with their skills and training, to provide legal help to disadvantaged people.

The law school simultaneously answers that question implicitly by funding an in house clinic and requiring all students to complete the clinical component. 'Law school clinics continue to play an important role in making access to justice a reality for many low-income people. They do so not only by exposing law students to the 
legal problems that the poor face but also by allowing students to experience what amounts to a "tactile" connection with the obligation to find substantive and creative ways to respond to unmet legal needs. ${ }^{50}$

This is another aspect of this first point which students learn through their clinical component. The law school models the answer to the question of what responsibility does each legal practitioner have to the law and the legal system.

\section{Student autonomy}

This is the $2^{\text {nd }}$ element of the ethical legal professional which is taught through the clinical component.

Students do not observe interviewing of clients with legal problems, or only role play it, rather they actually interview real clients. This ideally supports a sense of purpose in students' lives. According to Ryan and Deci 'the needs for autonomy, competence, and relatedness "appear to be essential for facilitating optimal functioning of the natural propensities for growth and integration, as well as for constructive social development and personal well-being." "51 They developed selfdetermination theory which explains what 'helps people to thrive and maximize positive motivation'. Experiences of autonomy and relatedness, such as interviewing clients in a supportive environment, is the type of experience which

\footnotetext{
50 Margaret Martin Barry and Peter A. Joy, 'Clinical Education for This Millenium: The Third Wave', 7 Clinical L. Rev. 1 2000-2001.

${ }^{51}$ Leah Wortham, Catherine Klein and Beryl Blaustone, Autonomy-Mastery-Purpose: Structuring Clinical Courses to Enhance These Critical Educational Goals. 17-18 Int'l J. Clinical Legal Educ. 105 2012, p 113, quoting Ryan and Deci, Self Determination Theory and the Facilitation of Intrinsic Motivation, Social Development, and Well Being, 55 Am. Psych. 6868 (2000) Rev
} 
would maximize positive motivation in students and help them to thrive. This is an issue which would warrant further research with the student group.

Students comment informally about the impact of being responsible for interviewing the client, finding out what the client needs help with and how they can contribute to that. For many it is their first experience of seeing how law can help people and how impenetrable the legal system can be for disadvantaged people. Most students are very nervous about whether they will be able to successfully interview clients before they interview. Almost all students feel a sense of accomplishment at the end of the evening advice clinic when they have interviewed clients. In their reflection assignment they readily identify areas for improvement but also refer to what they are able to achieve in their interview. Through this it appears that the clinical component builds students' sense of autonomy and builds their motivation. These accounts are anecdotal and warrant further empirical research.

\section{How does the clinical component teach students the importance of reflection and ongoing improvement?}

This is the $3^{\text {rd }}$ of the key elements found in the various definitions of what makes an ethical legal professional. Rather than assume that experience itself will teach students, the importance of de-brief and reflection is essential. Students need the 
opportunity to talk with each other about what they are learning and reflection is a key part of the learning process ${ }^{52}$.

This occurs both formally and informally through the clinical component in ethics at UNSW. Students are encouraged to discuss their experiences informally in a group setting at the end of, and during the interview advice clinic. They are also asked to complete a formal assignment reflecting on their interview experience. There are two aspects of reflection which should be addressed here.

One is the student's self reflection, about how the interviewer conducted the interview, areas for improvement and issues which arose between the interviewer and interviewee. The other area for reflection is about ethical issues which may have arisen or broader issues around the law and legal system and the client's participation within it. Both these areas of reflection are included in the reflective assignment. Generally students are able to effectively answer the question reflecting on their own interviewing practice ${ }^{53}$. Their ability to reflect on the legal system and the law varies.

The Best Practices include reflection as a vital element within clinical components stating:

In all clinical courses and components, debriefing and discussion that encourages reflection are emphasised. Further structured opportunities for reflection are a

\footnotetext{
${ }^{52}$ Peter Joy, The Ethics of Law School Clinic Students as Student-Lawyers, 45 South Texas L.Rev 815 at 839

${ }^{53}$ There is no empirical evidence of the students' ability to reflect, however the clinical component has been in place for over 14 years and a large number of reflective assignments, demonstrating reflective ability have been submitted for assessment.
} 
clearly articulated and important part of any clinical course. Reflection is informed by relevant literature and incorporated into every clinical course in a structured, planned and thoughtful way ${ }^{54}$.

In this way the clinical component is structured to meet the best practices. The assessment of reflection will be discussed further below.

There are additional learnings that students gain from their clinical component and these will now be discussed.

\section{MODELLING COLLABORATIVE TEAM WORK AND DEMONSTRATING A}

\section{PARTICULAR TYPE OF LEGAL PRACTICE}

In addition to teaching ethics and ethical decision making formally, the methodology of teaching is equally important. If one of the values which is sought to be taught, is collaborative team work, then this must be modelled ${ }^{55}$. It is vital therefore that in supervision the clinical supervisor demonstrates respectful and mutual relationships with volunteer supervisor solicitors. The relationship between clinical supervisor and volunteer solicitor supervisor must use clear communication.

\footnotetext{
${ }^{54}$ Best Practices in Australian Clinical legal education, , http://www.olt.gov.au/project-strengtheningaustralian-legal-ed-clinical-experiences-monash-2010, Adrian Evans, Anna Cody, Anna Copeland, Jeff Giddings, Mary Anne Noone, Simon Rice. Office for Learning and Teaching, 2013. p 58.

${ }^{55}$ Lustbader, Walk the Talk: Creating Learning Communities to Promote a Pedagogy of Justice 4 Seattle J Soc Just 613, 628.
} 
Discussing professional values in a clinical setting can assist students to begin to identify their own professional sense, and so be better able to assess in the future whether a particular practice will suit their professional identity ${ }^{56}$. The role of a clinical office being a role model in legal practice about how a legal practitioner should behave and what ethical decision making means, cannot be overrated. By providing the opportunity to all $1^{\text {st }}$ or $2^{\text {nd }}$ or $3^{\text {rd }}$ year students to participate in the clinical component situated at a functioning community legal centre, students are given the chance to participate in a particular type of legal practice and begin thinking about whether that type of legal practice is one which would suit their values, and their approach to law. It shows other legal professionals volunteering their time, and so, by example they are shown that other legal professionals believe they should contribute to the community with their legal knowledge. It indirectly addresses the issue of 'what responsibility does each legal professional have to contribute to the community?'

Students have modelled for them, ways of being a lawyer with disadvantaged clients. They also have collaborative team work modelled as the supervising clinical supervisor solicitor works with the volunteer supervisor solicitors. They are given a high degree of responsibility through actually taking instructions from clients, briefing the supervising solicitor and researching the law and writing up the advice given. Through the reflection assignment and informally at the advice session,

\footnotetext{
${ }^{56}$ Tony Foley, Margie Rowe, Vivien Holmes and Stephen Tang "Teaching professionalism in legal clinic- what new practitioners say is important" International Journal of Clinical Legal Education, Vol. 17, 2012, 26.
} 
students reflect on aspects of the law, the legal system, their own interviewing skills and the experience of the client. This aspect, teaching student autonomy, is another critical learning.

\section{TRAINING OF SUPERVISORS WITHIN THE CLINICAL COMPONENT AND} ASSESSMENT

As discussed above under the first point, students are expected to be able to reflect on a range of issues, including the client's and their own place in the legal system and ethical issues which arise. Ideally students during the evening advice clinic discuss with their volunteer lawyer supervisors aspects of their experience. The volunteer lawyer supervisors should also be able to give them formative feedback about their performance. This capacity will vary substantially among the volunteer lawyer supervisors. The Best Practices Report discusses the importance of assessing reflection, using a criterion-based approach that focuses on both the reflective process, the content of the reflection, and the linkage to learning outcomes ${ }^{57}$.

Currently students' interviews are not formally assessed using criterion-based standards although ideally volunteer lawyer supervisors are expected to give formative feedback. Students will often raise difficulties they faced while

\footnotetext{
${ }^{57}$ Best Practices in Australian Clinical legal education, , http://www.olt.gov.au/project-strengtheningaustralian-legal-ed-clinical-experiences-monash-2010, Adrian Evans, Anna Cody, Anna Copeland, Jeff Giddings, Mary Anne Noone, Simon Rice. Office for Learning and Teaching, 2013. P59.
} 
interviewing and the volunteer lawyer supervisors, as well as the supervising clinical solicitor, give feedback about how to improve the interviewing practice. The reflection assignment, which follows the interviewing experience, is the summative assessment of the clinical component, which assesses the students' ability to evaluate their own interviewing, as well as their thinking about their own current and future contribution to the law and legal system. There are 3 questions within this assignment and the mark contributes to $15 \%$ of the overall grade students receive for the course. There is a published assessment ${ }^{58}$ rubric which outlines which aspects are assessed ${ }^{59}$. Students ideally draw on set readings about good interviewing practice $^{60}$ and identify how they were or were not able to use good interviewing practice. Students must identify how they can improve in the future. They don't have the opportunity to interview further clients.

In this way the clinical component reflects the insight from Stuckey et al that ‘optimal learning from experience involves a continuous, circular four stage sequence of experience, reflection, theory and application.' ${ }^{61}$ By including a

\footnotetext{
${ }^{58}$ 'Formal assessment, using publicised criteria, is combined with informal feedback delivered when opportunity presents itself or necessity requires it', Best Practices in Australian Clinical legal education, http://www.olt.gov.au/project-strengthening-australian-legal-ed-clinical-experiences-monash-2010, Adrian Evans, Anna Cody, Anna Copeland, Jeff Giddings, Mary Anne Noone, Simon Rice. Office for Learning and Teaching, 2013.

${ }^{59}$ The rubric informs students that their identification of ethical issues is assessed, the ability to apply ethical frameworks to real life situations, their reflection on experience, their identification of good interviewing technique and their ability to incorporate theory from readings into reflection on practical experience.

${ }^{60}$ These are readings which are assigned for the formal class on interviewing including Kay Lauchland, Ch 3 , 'The Importance of good communication', Legal Interviewing: Theory, Tactics and Techniques, KA Lauchland and MJ Le Brun, Butterworths Australia, 1996 ; Chapter 2, 'Interviewing-Listening and Questioning', Ross Hyams, Susan Campbell, Adrian Evans, , Practical Legal Skills: Developing New Clinical Technique, $4^{\text {th }}$ ed, Oxford University Press, Australia and New Zealand 2014.

${ }^{61}$ Stuckey and Others, Best Practices for Legal Education, A Vision and a Road Map, Clinical Legal Education Association, 2007.
} 
reflective assignment, which draws on theory, the clinical component teaches students the significance of that circular process.

Within the clinical component delivered through Kingsford Legal Centre at UNSW, volunteer supervisor solicitors who are actively working with students, guide them in taking client instructions, work with them to develop legal advice for the client, supervise their note taking and written summaries of client advice. These volunteers are not given formal training for their role teaching students. There are also clinical supervising solicitors who are trained in clinical supervision who supervise the volunteer supervisor solicitors and who provide on-the-job training through modelling appropriate student teaching and supervision. The volunteer supervisor solicitors do get training in relevant areas of law within a community legal practice, but no training on how to supervise students. One of the concerns has been that it may be too taxing on volunteer supervisor solicitors to require them to also gain training in supervision skills when they are donating their time to the Centre for disadvantaged clients. Anecdotally however, many of the volunteer supervisor solicitors also comment on the pleasure they gain in working with law students and supervising their work ${ }^{62}$.

At the very least, training in supervision skills should be offered to all volunteer solicitor supervisors. Even if they don't immediately identify the usefulness of

\footnotetext{
${ }^{62}$ Each year there is an annual dinner to thank volunteer solicitors at Kingsford Legal Centre, at which many of the volunteer solicitors offer their observations of the sense of worth and pleasure they gain from supervising law students.
} 
receiving training in their supervising of students, supervision skills will be transferable to their workplaces where they may supervise other employees.

The Best Practices make clear that:

"All supervisors, including short-term, locum and agency-employed supervisors, [should be] trained in the process of supervision and provided with the time and resources to fulfil their responsibilities.

Supervisors [should be] able to participate in specific supervision training courses and skills development processes. Universities [will] give ongoing commitment to the professional development of supervisors" 63 .

If the aim of the clinical component is to teach the 3 elements outlined above, then it is key that the volunteer lawyer supervisors are trained how to teach these elements. Due to the differences among the group of volunteer lawyers, some from private practice, others from large commercial law firms, others from legal aid practices, they would need an opportunity to reflect themselves on the sorts of issues which arise in interviewing disadvantaged clients. Training would provide opportunity for the volunteer lawyer supervisors to reflect on these issues. They could also be asked for their views on 'good interviewing practice'. As they are experienced lawyers, there would be room for ample discussion of both these issues in the

\footnotetext{
${ }^{63}$ Best Practices in Australian Clinical legal education, http://www.olt.gov.au/project-strengthening-australianlegal-ed-clinical-experiences-monash-2010, Adrian Evans, Anna Cody, Anna Copeland, Jeff Giddings, Mary Anne Noone, Simon Rice. Office for Learning and Teaching, 2013. P56.
} 
process of teaching them to teach the students how to reflect on their role as future lawyers contributing to the community and the need for continual improvement and ongoing reflection. At a base level, due to each lawyer volunteering their time, at the least, these lawyers/supervisors believe they have a responsibility to contribute in some form to the community. Small group discussion about both of these aspects would be an effective mechanism to train them. The volunteer lawyer supervisors may then need further support during the advice clinics in encouraging students to think critically about their role, and their interviewing.

In order to train the lawyers to teach student autonomy it would be useful to outline some of the history of clinical legal education methodology and the importance of giving students responsibility ${ }^{64}$ for their work within that. From this a range of ways of encouraging autonomy could be discussed such as students participating in researching advice, students' views being sought about clients' issues, students writing up of the advice being constructively critiqued. The broader linking between personal values and self motivation could also be taught with some references provided to the volunteer lawyer supervisors for their further reading. Another aspect of developing student autonomy is giving effective and timely feedback. This is also recognised in the best practices which state that:

"frequency of feedback [should be] planned before the use of clinical components to ensure

\footnotetext{
${ }^{64}$ Simon Rice, (1996), A Guide to Implementing Clinical Teaching Method in the Law School Curriculum; Jeff Giddings, Clinical Legal Education in Australia: A Historical Perspective, 3 Int'I J. Clinical Legal Educ. 7 2003; Catherine Klein, Leah Wortham and Beryl Blaustone, Autonomy-Mastery-Purpose: Structuring Clinical Courses To Enhance These Critical Educational Goals, 17-18 Int'l J. Clinical Legal Educ. 1052012
} 
that such feedback is consistent across the student body; and supports the clinical process." 65

To train the lawyers to teach ongoing reflection, ideally the volunteer lawyer supervisors would be trained to ask at the end of each interview "What did we do well? And what could we do better?". This could then model to the student the importance of self assessment and critique on an ongoing basis. The volunteer lawyer supervisor could also be encouraged to reflect on their interviewing of the client and model the analysis of what worked well, and what could be improved with the client. The volunteer lawyer supervisors could engage in role plays in training in order to develop their skills in these areas.

After this training, the following challenge would be to measure whether the students are learning these 3 elements. Currently the only way of measuring this is through the content of the reflective assignment completed by each student. These demonstrate that most students are able to reflect on their future role as a lawyer and critique their own interviewing. To assess whether they are learning autonomy is more difficult. The only mechanism is the student's own evaluation of their sense of growth and learning through the experience. Learning about the need for ongoing improvement and self reflection can probably be measured through the reflection assignment and also a student's before, and after, self evaluation. Empirical research on each of these aspects, asking students to give their views on each aspect both

\footnotetext{
${ }^{65}$ Best Practices in Australian Clinical legal education, , http://www.olt.gov.au/project-strengtheningaustralian-legal-ed-clinical-experiences-monash-2010, Adrian Evans, Anna Cody, Anna Copeland, Jeff Giddings, Mary Anne Noone, Simon Rice. Office for Learning and Teaching ,2013, p 57.
} 
before, and after their clinical component may provide a means to measure the impact of the learning through the clinical component.

\section{CHALLENGES OF A CLINICAL COMPONENT WITHIN A SUBSTANTIVE LAW}

\section{SUBJECT}

From this brief discussion, it is apparent that there are valuable learnings on ethical practice and decision making for students, even within a brief 5 hour, interview advice session, clinical component. Integrating clinical experiences and methodologies into the substantive curriculum has been discussed and generally recognized as a valuable innovation within legal education ${ }^{66}$. Other law schools have attempted to incorporate clinical elements within substantive courses such as at the University of Maryland, University of New Mexico and New York University. ${ }^{67}$ Working with actual clients within the first or second year is not widely adopted and yet has distinct advantages.

There are 2 distinct areas for improvement and growth within the clinical component.

The integration between the clinical component and the substantive ethics subject at UNSW Law can be challenging. While the 3 specific elements discussed are taught

\footnotetext{
${ }^{66}$ Margaret Martin Barry and Peter A. Joy, 'Clinical Education for This Millenium: The Third Wave', 7 Clinical L. Rev. 1 2000-2001

${ }^{67}$ Margaret Martin Barry and Peter A. Joy, 'Clinical Education for This Millenium: The Third Wave', 7 Clinical L. Rev. 1 2000-2001, p44.
} 
within the clinical component, the greater challenge is 'how to get the most' out of a valuable and rare clinical component within a substantive law subject across the cohort of students. A community law centre, which is largely in- house, cannot offer a clinical learning experience in a range of substantive law subjects especially when there are over 180 students each semester. It is too resource intensive. As some of the learning is individually based, ways to encourage peer-to peer learning, and deepen the learning from the clinical component, should be explored. These possible approaches could include introducing an individual oral presentation to the class, as an assessment alternative, and attributing marks for class participation where students use their clinical component to describe or analyse ethical issues in discussions occurring during the course.

The second area for growth is in training volunteer lawyer supervisors to teach the 3 elements more effectively and to explore effective assessment of these. This has been discussed at length above.

\section{CONCLUSION}

From this discussion, it is apparent that ethics training and awareness is a vital part of any legal education and career. Rather than focus on disciplinary consequences of malpractice, it is key to recognize that an ethical lawyer will identify their responsibility to contribute to the community, to the legal system and to improving 
justice for the community. They will also be committed to competent, self directed and autonomous lawyering. Ongoing reflection and continual improvement in their work will be a further aspect of their work. These 3 elements of what makes an ethical legal professional are developed, even in a short, sharp clinical component within a broader ethics course. Clinics have particular riches to offer the teaching of ethics. A relatively short clinical component within a substantive ethics subject will provide deep learning for students including these 3 key elements, as well as modelling teamwork and modelling the role of other legal professionals contributing to the community. The challenges include ensuring the training of all volunteer lawyer supervisors in supervision skills. As the supervisors will have varying skills and perspectives on the law and their role in the legal system, it is essential to provide a forum in which to explore their own interviewing practice, and values and beliefs around the role of lawyers in contributing to the community. Training in giving effective feedback, including using role plays will be an essential way to improve the clinical component. The other area for improvement is to gain as much from the individual experience and reflections of students, across the student cohort through some additional assessment options and sharing of individual experience in class time. Finally, it strengthens clinical components to use the best practices in clinical education to assist in their design. 